\title{
Fatty acids profile, atherogenic and thrombogenic health lipid indices in the meat of lambs that received canola grain
}

\section{Perfil de ácidos graxos, índices de lipídios aterogênicos e trombogênicos em carne de cordeiros alimentados com grãos de canola}

\author{
Mayara Mitiko Yoshiraha Carneiro ${ }^{1}$ (D); Rafael Henrique de Tonissi e Buschinelli de Goes ${ }^{1}$ (D); \\ Beatriz Cervejeira Bolanho Barros ${ }^{2}$ (D); Raquel Tenório de Oliveira ${ }^{1}$ (D); Alexandre Rodrigo Mendes Fernandes ${ }^{1}$ (iD); \\ Nayara Gonçalves da Silva ${ }^{1}$ (D); Douglas Gabriel Anschau ${ }^{1}$ (D); Claudia Andréa Lima Cardoso ${ }^{3}$ (D); \\ Sullyvan Silva Oliveira ${ }^{1}$ (D); Yasmin dos Santos Picanço ${ }^{1}$ \\ ${ }^{1}$ Universidade Federal da Grande Dourados, Faculdade de Ciências Agrárias, Dourados - MS, Brazil \\ ${ }^{2}$ Universidade Estadual de Maringá, Departamento de Tecnologia, Umuarama - PR Brazil \\ ${ }^{3}$ Universidade Estadual do Mato Grosso do Sul, Centro de Estudos em Recursos Naturais, Dourados - MS, Brazil
}

\begin{abstract}
This study evaluated the fatty acid composition and qualitative characteristics of meat from lambs feed in feedlot with increasing levels of canola grain. Meat obtained from 27 lambs fed 0, 8 and 16\% inclusion of canola grain were analyzed. There was a reduction in the content of saturated fatty acids (SFA): lauric, heptadecanoic, and stearic; and unsaturated fatty acids (UFA): palmitoleic, oleic, and eicosatrienoic, with the increasing levels of canola grain. There was a linear reduction for the $\omega 3$ acid and the $\omega 3: \omega 6$ ratio, while the $\omega 6: \omega 3$ ratio increased. But the values observed for this ratio $(\omega 6: \omega 3)$ were lower than 4 , which is considered a satisfactory value. There was a slight increase $(\sim 2 \%)$ for the thrombogenicity index and atherogenicity index with the inclusion of canola grain. There was a reduction in the hypocholesterolemic: hypercholesterolemic ratio, with mean values of 2.09 for the diet with $0 \%$ inclusion, and 2.06 for 8 and $16 \%$ inclusion of canola. Although the inclusion of canola grain for lambs decreased the content of some UFA, reflecting alterations in the correlated nutritional properties, there is a reduction of SFA. The results for instrumental analysis, proximate composition, and sensory acceptance of the lamb meat were similar among the treatments.
\end{abstract}

Keywords: Hypercholesterolemic fatty acids. Hypocholesterolemic fatty acids. Meat quality. Unsaturated fatty acids. Oilseeds.

\section{RESUMO}

Objetivou-se avaliar a composição dos ácidos graxos e as características qualitativas da carne de cordeiros terminados com níveis crescentes de canola grão na dieta. Foram estudadas amostras de carne provenientes de 27 cordeiros, confinados por 45 dias e alimentados com 00, 08 e 16\% de inclusão de canola grão. Houve efeito para os ácidos graxos saturados (AGS): laurico, heptadecanoico e esteárico; ácidos graxos monoinsaturados (AGMI): palmitoleico e oleico; e ácidos graxos polinsaturados (AGPI): eicosatrienoico. Estes ácidos reduziram à medida que os níveis da canola grão aumentaram. Para os AGMI, houve efeito com maior concentração no músculo dos cordeiros alimentados sem a canola grão (49,80\%). Houve uma redução linear para o ácido $\omega 3$ e para a relação $\omega 3: \omega 6$, enquanto que a relação $\omega 6: \omega 3$ aumentou. A canola grão influenciou o índice de aterogenicidade, com média de 0,57 para o tratamento com $0 \%$ de inclusão e 0,58 para os tratamentos com $8 \%$ e $16 \%$ de inclusão. Observou-se aumento linear para o índice de trombogenicidade com a inclusão da canola grão, cujas médias foram, respectivamente, $0,16,0,17$ e 0,18 para os tratamentos $0 \%, 8 \%$ e $16 \%$ de inclusão. Houve redução para a relação hipocolesterolêmicos-hipercolesterolêmicos, com médias de 2,09 para a dieta com $0 \%$ de inclusão, e 2,06 para 8\% e 16\% de inclusão da canola em grão na dieta. A canola grão não influenciou a análise instrumental, composição centesimal e atributos sensoriais da carne.

Palavras-chave: Ácidos graxos hipercolesterolêmicos. Ácidos graxos hipocolesterolêmicos. Ácidos graxos insaturados. Qualidade de carne. Oleaginosas. 
Correspondence to:

Rafael Henrique de Tonissi e Buschinelli de Goes

Universidade Federal da Grande Dourados, Faculdade de

Ciências Agrárias

Rodovia Dourados-Itahum, km 12 Caixa Postal 364.

CEP: 79804-970. Dourados - MS, Brazil

e-mail: rafaelgoes@ufgd.edu.br

Received: November 10, 2020

Approved: May 12, 2021

How to cite: Carneiro MMY, Goes RHTB, Barros BCB, Oliveira RT, Fernandes ARM, Silva NG, Anschau DG, Cardoso CAL, Oliveira SS, Picanço YS. Fatty acids profile, atherogenic and thrombogenic health lipid indices in the meat of lambs that received canola grain. Braz J Vet Res Anim Sci. 2021;58:e178023. https://doi.org/10.11606/ issn.1678-4456.bjvras.2021.178023

\section{Introduction}

The consumer market values carcasses of young animals because, under these conditions, the product will have higher quality and probably bring health benefits. The feedlot finishing of lambs can provide early slaughter, resulting in carcasses that meet market requirements, ensuring a faster return on invested capital. However, this system often presents unfavorable economic balance, mainly due to the food, responsible for much of the production costs. Therefore, the replacement of traditional foods with alternative sources is extremely important when the goal is to reduce the production cost (Yamamoto et al., 2013).

Ingredients and diet composition influence the fatty acid composition of meat from ruminants because the fatty acids that reach the duodenum are, at least in part, of dietary origin as well as the result of rumen microbial biohydrogenation of lipids (Buccioni et al., 2012). The type of fat added can influence the unsaturated fatty acid biohydrogenation in the rumen and fatty acid profiles in ruminant tissues (Kišidayová et al., 2014)

Canola is rich in unsaturated fatty acids, such as oleic

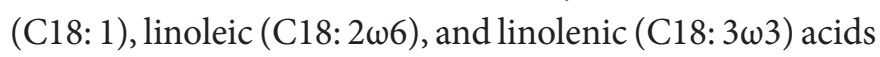
(Wada et al., 2008). Polyunsaturated fatty acids (PUFA) are called good fats, because they are important to every cell in the human body, and perform essential functions in the body. There are two main groups of PUFA: omega-3 ( $\omega 3$ ) and omega- $6(\omega 6)$. Both are considered essential as a human cannot synthesize them, and without them, the body does not function properly. Other polyunsaturated fats also have important functions, but they are not considered essential because the organisms of most people can produce them from linoleic and linolenic acids (Saldanha \& Gonzales, 2012).

However, the increase of some $\omega 6$ or $\omega 3$ acids, or the change in the ratio between them, can trigger the production of thromboxanes and leukotrienes, which, in excess, is associated with diseases such as thrombosis, arrhythmias, arthritis, asthma, and psoriasis (Rocha, 2008). PUFA may promote or prevent the onset of atherosclerosis and coronary thrombosis, based on their effects on serum cholesterol and low-density lipoprotein cholesterol. Therefore, the evaluation of the fatty acid (FA) profile is extremely important. Based on scientific studies, indices were developed to help in the nutritional assessment of food, highlighting the indices of atherogenicity and thrombogenicity, both related to the lipid fraction (Ulbricht \& Southgate, 1991), and blood cholesterol levels, which is related to the cardiovascular diseases in the human population (Oliveira et al., 2008).

Typically, the ratio of polyunsaturated and saturated fatty acids is used as a major index to evaluate the nutritional value of the fat (Bentes et al., 2009; Caldeira et al., 2010). However, this ratio is based on the chemical structure of FA and may not be the best way for this purpose, since it considers that all saturated fatty acids induce an increase in cholesterol and ignores the effects of monounsaturated fatty acids. Thus, the best method to assess the nutritional value of fat is the use of ratios based on the functional effects of FA, such as, for example, the ratio of hypocholesterolemic and hypercholesterolemic fatty acids (Bruker Advance III $700 \mathrm{MHz}$, Billerica, MA, USA h: H) (Caldeira et al., 2010).

In addition, other characteristics of meat quality traits can be affected by the type of feed administered to animals, such as color, water-holding capacity, $\mathrm{pH}$, composition, and tenderness (Quiñones et al., 2019). The inclusion of canola meal did not affect the meat quality of Mutton Merino lambs and pigs, respectively (Little et al., 2015; Sekali et al., 2016). The production system can alter the FA composition, especially PUFA, that affects meat sensory properties (Sañudo et al., 2000). However, works about the effects of diets with canola grains inclusion in the lamb meat properties are scarce, especially about sensorial attributes.

Based on the context, this study aimed to evaluate the quality traits, fatty acid profile, and sensory properties of meat from feedlot lambs receiving canola grain in the diet.

\section{Material and Methods}

The experiment was conducted in the Ovine Sector of the Experimental Station in the Animal Nutrition Laboratory and Meat Technology Laboratory, Federal University of Grande Dourados/UFGD, and at the Laboratory for 
the evaluation of oilseed by-products, at the Center of Research Laboratories in Agroenergy and Environmental Conservation (LAPAC/FINEP), located in the municipality of Dourados, state of Mato Grosso do Sul, between October and December 2012. This experiment was conducted following the rules of the Ethics Committee on Animal Experimentation in this institution, according to the opinion 021/2012 - CEUA/UFGD.

Whole Santa Ines male sheep $(\mathrm{n}=27)$ with an initial weight of $19.33 \pm 1,39 \mathrm{~kg}$ and age of 5 months were randomly and individually housed and identified. Then, animals were subjected to 14 days of adaptation to the diet, management, and facilities for later data collection.

The treatments consisted of three levels of inclusion of canola grain, on a dry matter basis (\% DM): 00,08 , and $16 \%$. Diet was weighed and supplied as a complete feed. The mixture was made at the time of supply (silage + concentrate), individually ad libitum, in two daily meals (08:00 $\mathrm{h}$ am and $16: 00 \mathrm{~h}$ ), allowing $10 \%$ leftovers of the amount provided by the calculated margin of the previous day and water ad libitum. Corn silage was the forage used and the concentrates were balanced according to NRC (National Research Council, 2007) to be isonitrogenous (Table 1) to provide gains of $200 \mathrm{~g} /$ day. The forage: concentrate ratio was 10:90 in DM.

The length of the experimental period ( 45 days), and the criterion for slaughtering animals, were defined by the time required to reach body condition three (3.0), on a scale of one (1.0) to five (5.0), for standardization of the degree of carcass finishing, as described by Osório et al. (2012). Lamb weight was determined at the beginning (initial body weight-BWi), every 14 days, and at the end

Table 1 - Proximate and chemical composition of experimental diets, on a dry matter basis

\begin{tabular}{crrr}
\hline \multirow{2}{*}{ Ingredient (\%) } & \multicolumn{3}{c}{ Level of canola grain (\%) } \\
\cline { 2 - 4 } & $\mathbf{0 0}$ & $\mathbf{0 8}$ & \multicolumn{1}{c}{$\mathbf{1 6}$} \\
\hline Corn silage & 10.00 & 10.00 & 10.00 \\
Corn grain & 67.73 & 63.44 & 59.15 \\
Soybean meal & 20.27 & 16.56 & 12.85 \\
Canola grain & 0.00 & 8.00 & 16.00 \\
Mineral mix & 2.00 & 2.00 & 2.00 \\
\hline Chemical composition (\%) & & & \\
\hline Dry matter & 78.87 & 79.44 & 79.27 \\
Crude protein & 16.69 & 15.82 & 16.52 \\
Ether extract & 3.49 & 6.18 & 8.87 \\
Neutral detergent fiber & 42.26 & 34.10 & 42.88 \\
Acid detergent fiber & 10.75 & 12.51 & 11.56 \\
Mineral matter & 4.73 & 4.34 & 4.82 \\
Total carbohydrates & 75.09 & 73.66 & 69.79 \\
Total digestible nutrients & 66.87 & 71.53 & 66.51 \\
\hline
\end{tabular}

${ }^{1}$ Mineral Supplement (nutrients per kilogram of product): phosphorus $80 \mathrm{~g}$; calcium 140g; magnesium 7g; sulfur 12g; sodium $133 \mathrm{~g}$; 4,200 mg zinc; 300 mg copper; $800 \mathrm{mg}$ manganese; $1500 \mathrm{mg}$ iron; $100 \mathrm{mg}$ cobalt; $150 \mathrm{mg}$ iodine; selenium $15 \mathrm{mg}$; fluoride (max) $800 \mathrm{mg}$, phosphorus solubility of citric acid $2 \%(\min ) 95 \%$. (final body weight (BWf) of the experimental period. Body score was determined during animal weighing by palpation of the lumbar region and insertion of the tail. The final body weight was $26.46 \pm 1.6 \mathrm{~kg}$ and carcass weight of $11.87 \pm 0.72 \mathrm{~kg}$.

A total of 27 left hind limbs was used. With the aid of a scalpel, Semimembranosus muscles were separated for instrumental analysis and fatty acid profile analysis. Semitendinosus muscles were used for proximate composition analysis and Biceps femoris muscles for sensory properties. All the samples were frozen at $-20^{\circ} \mathrm{C}$. The steaks were vacuum packaged and transferred to the lab.

The $\mathrm{pH}$ and temperature $\left(\mathrm{T}^{\circ} \mathrm{C}\right)$ were determined immediately after slaughter $\left(\mathrm{pH}\right.$ and $\left.\mathrm{T}^{\circ} \mathrm{C} 45 \mathrm{~min}\right)$ using a portable digital $\mathrm{pH}$ meter (Testo 205), with the introduction of the electrode directly into the Semimembranosus muscle. Carcasses were transferred to cold storage at $4^{\circ} \mathrm{C}$ for $24 \mathrm{~h}$, and $\mathrm{pH}$ and $\mathrm{T}^{\circ} \mathrm{C} 24 \mathrm{~h}$ were again determined.

For proximate composition analysis, the Semitendinosus muscle was homogenized in a food processor to obtain a homogeneous mass. The crude protein (CP) (\# 990.03), total lipids (\#945.16), moisture (\#935.29), and ash (\#942.05) were determined according to the Association of Official Analytical Chemists (2000).

On the day of the evaluation, the samples were thawed in the refrigerator $\left(10^{\circ} \mathrm{C}\right)$ and cut into $2.5 \mathrm{~cm}$-thick steaks using a standardized scale. Muscle color was determined by using a Minolta Chroma Meter CR-400 calibrated to a white tile standard, using the CIE system $\left(\mathrm{L}^{*}, \mathrm{a}^{*}, \mathrm{~b}^{*}\right)$, in which $\mathrm{L}^{*}$ is brightness, $\mathrm{a}^{*}$ is redness and $\mathrm{b}^{*}$ is yellowness. After color evaluation, $2.0 \mathrm{~g}$ of sample was taken and subjected to a weight of $25 \mathrm{~kg} \mathrm{~min}^{-1}$ for determining the water holding capacity (WHC), according to the methodology described by Cañeque \& Sañudo (2000).

Cooking loss was determined using an electric oven (Philco) preheated at $170^{\circ} \mathrm{C}$. Raw meat samples were weighed and placed on trays with an iron grate. They were then transferred to an oven, where they remained until the internal temperature of the sample center was $75^{\circ} \mathrm{C}$, this being determined temperature with a portable skewer type digital thermometer (Akso). After cooling to room temperature, samples were again weighed to calculate the percentage of loss during cooking. The shear force of the Semimembranosus was determined using five cylinders of $1.3 \mathrm{~cm}$ in diameter in the longitudinal direction of muscle fibers, and subjected to cutting in the transverse direction of the muscle fibers, using a Warner-Bratzler blade coupled to a Texture Analyzer TA-XT2i. The values were expressed in kilogram-force (kgf).

The fatty acid profile of canola grain (Table 2) and lamb meat was determined according to the recommendations of 
Folch et al. (1957). The lipids were extracted from lamb meat samples using a mixture of chloroform-methanol $(2: 1, \mathrm{v} / \mathrm{v})$. Transesterification of triglyceride acids was achieved using a solution of $\mathrm{n}$-heptane and $\mathrm{KOH} /$ methanol. The grease material (200 $\mathrm{mg}$ ) was transferred to a $10 \mathrm{~mL}$ test tube with a screw lid, to which $2.0 \mathrm{~mL}$ of $\mathrm{n}$-heptane was added. The material was agitated until complete solubilization of the fatty matter. Then, $2.0 \mathrm{~mL}$ of $2 \mathrm{~mol} / \mathrm{L} \mathrm{KOH}$ in methanol were added and the solution was mixed vigorously for $5 \mathrm{~min}$. The test tubes were tightly closed, protected from light, and stored at $-18^{\circ} \mathrm{C}$ for further chromatographic analysis.

Fatty acid analyses were carried out a gas chromatography using a flame ionization detector gas chromatograph. A fused silica capillary column of $100 \mathrm{~m} \times 0.25 \mathrm{~mm} \times 0.20 \mu \mathrm{m}$ was used for elution. The oven temperature was programmed as follows: initial temperature $100^{\circ} \mathrm{C}$, initial hold, $1 \mathrm{~min}$, and then raised to $170^{\circ} \mathrm{C}$ at $6.5^{\circ} \mathrm{C} \mathrm{min}^{-1}$. Subsequently, there was another rise from 170 to $215^{\circ} \mathrm{C}$ at $2.7^{\circ} \mathrm{C} \mathrm{min}{ }^{-1}$ and hold for $30 \mathrm{~min}$. Finally, there was a rise from 215 to $230^{\circ} \mathrm{C}$ at $4^{\circ} \mathrm{C} \mathrm{min}^{-1}$. The temperatures of the injector and detector were 270 and $280^{\circ} \mathrm{C}$, respectively. Samples of $0.5 \mu \mathrm{L}$ were injected in split mode using nitrogen as a carrier gas at a drift velocity of $1 \mathrm{~mL} \mathrm{~min}^{-1}$. Chromatograph peaks of fatty acids were identified by comparison with retention time using a mixture of Sigma (St Louis, MO, USA) standards,

Table 2 - Lipid profile of canola grain

\begin{tabular}{lc}
\hline \multicolumn{1}{c}{ Fatty acid } & Canola grain (\%) \\
\hline C8:0 (Caprylic) & 0.438 \\
C10:0 (Capric) & 0.227 \\
C11:0 (Undecanoic) & 0.002 \\
C14:0 (Myristic) & 2.466 \\
C16:0 (Palmitic) & 18.524 \\
C17:0 (Heptadecanoic) & 2.304 \\
C18:0 (Stearic) & 27.818 \\
C20:0 (Arachidic) & 1.101 \\
C22:0 (Benic) & 0.029 \\
C24:0 (Lignoceric) & 0.516 \\
C15:1 (Pentadecenoic) & 0.002 \\
C16:1 (Palmitoleic) & 3.262 \\
C17:1 (Cis-10-Heptadecanoic) & 0.013 \\
C18:1 (Oleic) & 26.868 \\
C22:1 $\omega 9$ (Erucic) & 6.265 \\
C18:2 $\omega 6 t$ (Linolelaidic) & 1.191 \\
C18:2 $\omega 6$ (Linoleic) & 8.918 \\
C18:3 $\omega 6$ ( -linolenic) & 0.002 \\
C20:3 $\omega 6$ (Dihomo- - -linolenic) & 0.008 \\
C20:3 $\omega 3$ (Eicosatrienoic) & 0.014 \\
C20:4 $\omega 6$ (Arachidonic) & 0.029 \\
C20:5 $\omega 3$ (Icosapentaenoic) & 0.002 \\
C22:6 $\omega 3$ (Docosahexaenoic) & 0.001 \\
\hline &
\end{tabular}

and the nonadecanoic acid (19:0) was used as an internal standard. Quantification of fatty acids was performed using correction factors for peak areas and internal standard-based calculations, and the results were expressed in $\mathrm{mg} / \mathrm{g}$ of tissue.

We also determined the atherogenicity index $(\mathrm{AI})=[(\mathrm{C} 12: 0+(4 \times \mathrm{C} 14: 0)+\mathrm{C} 16: 0)] /\left(\sum \mathrm{AGMI}+\sum \omega 6+\sum \omega 3\right)$ and the thrombogenicity index $(\mathrm{TI})=(\mathrm{C} 14: 0+\mathrm{C} 16: 0+\mathrm{C} 18: 0) /$ $\left[\left(0,5 \times \sum\right.\right.$ AGMI $)+\left(0,5 \times \sum \omega 6+\left(3 \times \sum \omega 3\right)+\left(\sum \omega 3 / \sum \omega 6\right)\right]$ according to Ulbricht \& Southgate (1991), and the ratio of hypocholesterolemic and hypercholesterolemic fatty acids $(\mathrm{h}: \mathrm{H})=$ $(\mathrm{C} 18: 1$ cis $9+\mathrm{C} 18: 2 \omega 6+20: 4 \omega 6+\mathrm{C} 18: 3 \omega 3+\mathrm{C} 20: 5 \omega 3+\mathrm{C} 22: 5 \omega 3$ $+\mathrm{C} 22: 6 \omega 3) /(\mathrm{C} 14: 0+\mathrm{C} 16: 0)$ by the method of Santos-Silva et al. (2002).

Sensory evaluations were conducted in the muscle Biceps femoris (devoid of subcutaneous fat), which was roasted at $170^{\circ} \mathrm{C}$, until reaching an internal of $75^{\circ} \mathrm{C}$ and then rested at room temperature for $10 \mathrm{~min}$. According to the methodology described by Campo (2005), 80 untrained tasters of different ages, sheep meat lovers, were invited to participate in the study. Samples were placed by the different treatments on plates identified with tags, but so that the tasters did not know the treatments. In the descriptive test, we applied a 5 point-hedonic scale considering the attributes odor, flavor, tenderness, overall evaluation, and purchase intent. The five points of the scale were: $1-$ like extremely; 2 - like moderately; 3 - neither like nor dislike; 4 - dislike moderately and 5 - dislike extremely.

All statistical analyses were run using PROC UNIVARIATE and PROC MIXED of Statistical Analysis System 9.2, at 0.05 probability. The statistical design was completely randomized (DIC). The statistical model is shown below:

$Y i j=\mu+\alpha i+\varepsilon i j$

in which Yij represents the observation of canola grain level $i$ in animal $j$; ai represents the fixed effect of canola grain $i$ $(i=1,2,3)$, and $\varepsilon i j$ represents the random error.

Sensory data were analyzed using a Kruskal-Wallis nonparametric test, at 0.05 probability.

\section{Results and Discussion}

The inclusion of canola grain in the diet did not influence the initial and final $\mathrm{pH}$, initial and final temperature, cooking loss, shear force, water holding capacity, lightness $\left(L^{\star}\right)$, redness $\left(\mathrm{a}^{*}\right)$, and yellowness $\left(\mathrm{b}^{*}\right)$ (Table 3 ). The same effect was reported by Smeti et al. (2018), which investigated the effect of dose and administration form of rosemary essential oils on lamb meat quality.

The initial (45 $\mathrm{min}$ ) and final ( $24 \mathrm{~h}) \mathrm{pH}$ values of the leg were 6.78 and 5.76, respectively (Table 3 ). This result is due to the nutritional status of animals and because slaughtering 
Table 3 - Fatty acid profile in the Semimembranosus muscle of lambs finished with increasing levels of canola grain in the diet

\begin{tabular}{|c|c|c|c|c|c|}
\hline \multirow[t]{2}{*}{ Fatty acid } & \multicolumn{3}{|c|}{$\begin{array}{l}\text { Level of canola } \\
\text { grain (\%) }\end{array}$} & \multirow[t]{2}{*}{ SEM } & \multirow[t]{2}{*}{ P-valor } \\
\hline & 00 & 08 & 16 & & \\
\hline
\end{tabular}

\begin{tabular}{lrrrrl}
\hline Saturated fatty acids & & & & & \\
C10:0 (Capric) & 0.12 & 0.11 & 0.11 & 0.0025 & 0.7900 \\
C12:0 (Lauric) & 0.12 & 0.12 & 0.11 & 0.0020 & $0.0039^{* 1}$ \\
C14:0 (Myristic) & 2.19 & 2.22 & 2.21 & 0.0120 & 0.3255 \\
C15:0 (Pentadecanoic) & 0.23 & 0.21 & 0.23 & 0.0069 & 0.4535 \\
C16:0 (Palmitic) & 22.83 & 23.09 & 23.02 & 0.0342 & 0.6545 \\
C17:0 (Heptadecanoic) & 1.66 & 1.61 & 1.60 & 0.0077 & $0.0005^{* 2}$ \\
C18:0 (Stearic) & 15.23 & 15.22 & 15.11 & 0.0190 & $0.0051^{* 3}$ \\
C20:0 (Arachidic) & 0.11 & 0.11 & 0.11 & 0.0021 & 0.2345
\end{tabular}

\section{Monounsaturated fatty acids}

\begin{tabular}{|c|c|c|c|c|c|}
\hline C14:1 (Myristoleic) & 0.10 & 0.11 & 0.11 & 0.0022 & 0.4553 \\
\hline C16:1 (Palmitoleic) & 1.69 & 1.66 & 1.63 & 0.0088 & $0.0071^{* 4}$ \\
\hline C18:1 (Oleic) & 47.90 & 47.88 & 47.74 & 0.0323 & $0.0387^{* 5}$ \\
\hline C20:1 (Eicosenoic) & 0.11 & 0.10 & 0.10 & 0.0015 & 0.1343 \\
\hline \multicolumn{6}{|c|}{ Polyunsaturated fatty acids } \\
\hline C18:2 w6 (Linoleic) & 3.98 & 3.99 & 3.97 & 0.0199 & 0.1603 \\
\hline C18:3 w3 (a-linolenic) & 0.20 & 0.19 & 0.20 & 0.0040 & 0.2904 \\
\hline C18:2 CLA (cis9-trans 11) & 0.50 & 0.50 & 0.54 & 0.0113 & 0.7762 \\
\hline C20:2 (Eicosadienoic) & 0.10 & 0.11 & 0.11 & 0.0012 & 0.1232 \\
\hline C20:3 w3 (Eicosatrienoic) & 1.51 & 1.46 & 1.33 & 0.0200 & $0.0000^{* 6}$ \\
\hline $\begin{array}{l}\text { C20:3 } \omega 6 \text { (Dihomo- } \gamma^{-} \\
\text {linolenic) }\end{array}$ & 0.11 & 0.11 & 0.10 & 0.0016 & 0.1602 \\
\hline C20:4 (Arachidonic) & 0.21 & 0.19 & 0.22 & 0.0083 & 0.1000 \\
\hline $\begin{array}{l}\text { C20:5 w3 } \\
\text { (Eicosapentaenoic) }\end{array}$ & 0.11 & 0.11 & 0.11 & 0.0029 & 0.1570 \\
\hline Saturated & 42.48 & 42.68 & 42.50 & 0.0321 & 0.2343 \\
\hline Monounsaturated & 49.80 & 49.75 & 49.58 & 0.0343 & $0.0059^{* 7}$ \\
\hline Polyunsaturated & 6.71 & 6.63 & 6.58 & 0.0360 & 0.3343 \\
\hline Conjugated linoleic acid & 0.50 & 0.50 & 0.54 & 0.0113 & 0.1342 \\
\hline Omega 3 & 1.81 & 1.75 & 1.64 & 0.0193 & $0.0000^{* 8}$ \\
\hline Omega 6 & 4.09 & 4.10 & 4.07 & 0.0203 & 0.3453 \\
\hline Omega 6: Omega 3 & 2.26 & 2.34 & 2.48 & 0.0287 & $0.0002^{* 9}$ \\
\hline $\begin{array}{l}\text { Polyunsaturated: } \\
\text { Saturated }\end{array}$ & 0.16 & 0.16 & 0.15 & 0.0009 & 0.1601 \\
\hline Atherogenicity index & 0.57 & 0.58 & 0.58 & 0.0055 & $0.0187^{* 10}$ \\
\hline Thrombogenicity index & 1.16 & 1.17 & 1.18 & 0.0075 & $0.0001 * 11$ \\
\hline $\mathrm{h}: \mathrm{H}$ & 2.09 & 2.06 & 2.06 & 0.0139 & $0.0097 * 12$ \\
\hline
\end{tabular}

$*=$ significant at $5 \%$ probability; SEM $=$ standard error of the mean. ${ }^{1} \mathrm{Y}=0,128974-0,00678205 \mathrm{X}\left(\mathrm{r}^{2}=0.46\right) ;{ }^{2} \mathrm{Y}=1.68051-0.0293590 \mathrm{X}$ $\left(\mathrm{r}^{2}=0.59\right) ;{ }^{3} \mathrm{Y}=15.3129-0.0625641 \mathrm{X}\left(\mathrm{r}^{2}=0.44\right) ;{ }^{4} \mathrm{Y}=1.71744-0.0282051 \mathrm{X}$ $\left(\mathrm{r}^{2}=0.41\right) ;{ }^{5} \mathrm{Y}=48.0083-0.0833333 \mathrm{X}\left(\mathrm{r}^{2}=0.27\right) ;{ }^{6} \mathrm{Y}=1.61538-0.0907692 \mathrm{X}$ $\left(r^{2}=0.84\right) ;{ }^{6} \mathrm{Y}=49.9340-0.111282 \mathrm{X}\left(\mathrm{r}^{2}=0.43\right) ;{ }^{7} \mathrm{Y}=1.90718-0.0860256 \mathrm{X}$ $\left(r^{2}=0.81\right) ;{ }^{8} Y=2.13098+0.114068 X\left(r^{2}=0.64\right) ;{ }^{9} Y=0.465651-0.0204129 \mathrm{X}$ $\left(\mathrm{r}^{2}=0.64\right) ;{ }^{10} \mathrm{Y}=0.56+0.0039 \mathrm{X}\left(\mathrm{r}^{2}=0.75\right) ;{ }^{11} \mathrm{Y}=1.15+0.0078 \mathrm{X}\left(\mathrm{r}^{2}=0.67\right) ;$ ${ }^{12} \mathrm{Y}=2.09-0.01086 \mathrm{X}\left(\mathrm{r}^{2}=0.75\right)$.

was carried out at the place of the experiment. This greatly reduced the pre-slaughter stress, an important factor for the final $\mathrm{pH}$. The values for final $\mathrm{pH}$ were close to the reported by Ripoll et al. (2012), 5.6, which is considered acceptable for lamb meat. For Bouton et al. (1971), pH is one of the main factors that act in the conversion of muscle into meat and plays a key role in food safety and meat quality.

Initial ( $45 \mathrm{~min}$ ) and final ( $24 \mathrm{~h}$ ) temperatures of the hind limbs were, respectively, $37.50^{\circ} \mathrm{C}$ and $8.02^{\circ} \mathrm{C}$ (Table 3 ). The correct drop in temperature and $\mathrm{pH}$ during the cooling process indicates that other quality parameters, such as water holding capacity, cooking loss, shear force, and color, will have satisfactory results, as they are influenced by temperature and $\mathrm{pH}$ (Bouton et al., 1971).

The proximate composition of meat from lambs finished with canola grain was not affected, with mean values of $77.17 \%$ for moisture; $1.05 \%$ for ash; $17.52 \%$ for protein; and 3.81\% for lipids (Table 3). According to Leão et al. (2012), the proximate composition of lamb meat is approximately $75 \%$ moisture, $19 \%$ protein, $4 \%$ fat, and $1.1 \%$ mineral matter and can be influenced by diet. These values are close to those reported herein.

Among the components of meat, water is the major constituent, and its content is inversely proportional to fat (Pinheiro et al., 2012), i.e., the higher the water content, the lower the fat. Santos et al. (2009) evaluated the use of $8 \%$ of canola in grain and by-products of canola (rapeseed meal and rapeseed cake) in the total diet of Santa Ines sheep and found no significant differences between treatments for the characteristic chemical composition of the flesh. The average observed for treatment with canola in grain were: 70.95\% moisture; $2.40 \%$ ash; $16.14 \%$ crude protein, and $9.72 \%$ fat.

The mean value found for cooking loss was $45.41 \%$, which is higher than that observed by Yamamoto et al. (2013), who worked with sunflower seeds in the diet for lambs and reported a mean value of $37.07 \%$ in the Semimembranosus muscle. This parameter is important for evaluating meat quality in the preparation for consumption (Costa et al., 2011), being a characteristic influenced by the water holding capacity (WHC) of the meat (Monte et al., 2012).

WHC in the Semimembranosus muscle presented a mean value of $68.75 \%$, higher than that recorded by Yamamoto et al. (2013) - 57.76\%. The WHC is technically and gastronomically important, as it conserves flavor, improves the cooking process, and is also related to tenderness and juiciness, important properties for consumer acceptance (Quiñones et al., 2019). Also, meats with higher WHC have lower losses of nutrients through exudate, because, along with the water, soluble proteins are lost, as well as lipids, vitamins, and minerals (Pinheiro et al., 2010; Zeola et al., 2007).

The mean values obtained for shear force ranged from 3.47 to $3.49 \mathrm{kgf}$, indicating that the meat of lambs in this study can be considered tender, according to values presented by Cezar \& Souza (2007). This variable can be 
influenced by many reasons, for example, level of nutrition, management practices before slaughter, faster onset of rigor mortis, $\mathrm{pH}$ at post-mortem, pre-slaughter temperature, onset and extension of glycolysis, used muscle, post-slaughter management, packaging conditions, and methodology for the determinations, such as temperature and time during the cooking process (Bonacina et al., 2011, Mu et al., 2020).

The mean values of lightness $\left(\mathrm{L}^{*}\right)$, redness $\left(\mathrm{a}^{*}\right)$, and yellowness $\left(b^{\star}\right)$ were $41.14 ; 22.97 ; 9.56$, respectively. Pinheiro et al. (2009) worked with sheep of different categories kept on Tifton 85 pasture in a rotational stocking, supplying concentrate daily, and found values of 40.10 for $\mathrm{L}^{\star} ; 14.10$ for $\mathrm{a}^{*}$, and 2.61 for $\mathrm{b}^{*}$ for the Semimembranosus muscle. These values are far from those observed in this study, except for the $L^{\star}$ value that was similar. Nevertheless, sheep meat usually shows variations from 30.03 to 49.47 for $\mathrm{L}^{*}$; from 8.24 to 23.53 for $\mathrm{a}^{*}$, and from 3.38 to 11.10 for $b^{*}$ (Sañudo et al., 2000). In this way, the results obtained in this study are within these ranges.

The fatty acid (FA) profile of the Semimembranosus muscle of lambs identified $20 \mathrm{FA}$, including eight saturated fatty acids (SFA), four monounsaturated fatty acids (MUFA), and eight polyunsaturated fatty acids (PUFA) (Table 4 ). The prevalence of oleic, palmitic, and stearic FA was per the commonly accepted values for lambs (Smeti et al., 2018).

Regarding SFA, there was a linear effect for the lauric acid (C12:0), which was reduced with the inclusion of canola grain. This is probably related to the lipid profile of the grain that did not contain this FA. Lauric (C12:0) and myristic

Table 4 - Chemical composition and instrumental analyses in the Semitendinosus muscle of lambs finished with increasing levels of canola grain in the diet

\begin{tabular}{|c|c|c|c|c|c|}
\hline \multirow[t]{2}{*}{ Variable } & \multicolumn{3}{|c|}{$\begin{array}{c}\text { Level of canola grain } \\
(\%)\end{array}$} & \multirow[t]{2}{*}{ SEM } & \multirow[t]{2}{*}{$\operatorname{Pr}>F$} \\
\hline & 00 & 08 & 16 & & \\
\hline \multicolumn{6}{|l|}{ Chemical composition } \\
\hline Moisture & 74.42 & 78.03 & 79.07 & 1.175 & 0.1600 \\
\hline Ash & 1.17 & 1.02 & 0.95 & 0.056 & 0.1000 \\
\hline Protein & 19.36 & 17.15 & 16.04 & 0.847 & 0.1340 \\
\hline Lipid & 4.44 & 3.52 & 3.48 & 0.445 & 0.1111 \\
\hline \multicolumn{6}{|l|}{ Instrumental Analysis } \\
\hline Initial pH & 6.79 & 6.72 & 6.82 & 0.056 & 0.1234 \\
\hline Final pH & 5.44 & 5.98 & 5.83 & & 0.3458 \\
\hline Initial temperature $\left(\mathrm{T}^{\circ} \mathrm{C}\right)$ & 37.75 & 38.25 & 36.58 & 0.353 & 0.1777 \\
\hline Final temperature $\left(\mathrm{T}^{\circ} \mathrm{C}\right)$ & 6.88 & 8.67 & 8.43 & 0.660 & 0.2342 \\
\hline Cooking loss (\%) & 46.30 & 44.38 & 45.55 & 0.724 & 0.1222 \\
\hline Shear force (kgf) & 3.47 & 3.49 & 3.48 & 0.145 & 0.1345 \\
\hline $\begin{array}{l}\text { Water holding capacity } \\
(\%)\end{array}$ & 66.97 & 71.19 & 68.10 & 0.831 & 0.1777 \\
\hline Lightness (L*) & 41.12 & 40.67 & 41.64 & 0.678 & 0.2134 \\
\hline Redness $\left(a^{*}\right)$ & 22.52 & 22.63 & 23.76 & 0.331 & 0.1334 \\
\hline Yellowness (b*) & 9.29 & 9.73 & 9.65 & 0.271 & 0.1335 \\
\hline
\end{tabular}

(C14:0) acids promote hypercholesterolemia and are related to increased low-density lipoprotein (LDL) in blood serum. This results in the incidence of cardiovascular diseases and sequelae, together with increasing levels of serum cholesterol, leading to arteriosclerosis (Lira et al., 2005).

The content of heptadecanoic (C17:0) and stearic (C18:0) acids also decreased with the inclusion of canola grain in the fed diet. According to Gallo et al. (2007), diets with high ether extract content have a lower percentage of C17:0 acid. This may have occurred in this study, because the diets with $0 \%, 8 \%$, and $16 \%$ inclusion canola grain showed increasing concentrations of lipids in the diet, with $3.49 \%, 6.18 \%$, and $8.87 \%$, respectively, and thus the concentrations of the C17:0 acid in sheep meat reduced. In ruminants, the half-life of free PUFA is relatively short due to their rapid hydrogenation by rumen microbes into the corresponding saturated configuration, having as final product the stearic acid (C18:0), if the biohydrogenation is complete (Buccioni et al., 2012; Kim et al., 2009). However, the reduction presented in the concentration of C18:0 acid indicates that the biohydrogenation of linoleic acid (C18:2) may have been incomplete (Loor et al., 2004). Meanwhile, stearic acid does not influence blood cholesterol levels (Madruga et al., 2006).

The concentration of palmitoleic MUFA (C16:1) was reduced $(\sim 3.5 \%)$ with canola grain in the fed diet. These acids are responsible for the metabolism of lipids, which may help balance the levels of HDL (good cholesterol) and LDL (bad cholesterol), reduce the blood sugar level, and promote the decrease of fat tissue surrounding the liver and heart (Radmann \& Costa, 2008).

Another MUFA that was also decreased $(\sim 0.4 \%)$ was the oleic acid (C18:1). Even so, it was predominant in the muscle of lambs. In agreement with Sañudo et al. (2000), a high concentration of C18:1 acid in the composition of intramuscular fat of ruminants has been reported in the literature. While the C18:1 acid helps to reduce blood cholesterol level, the palmitic FA (C16:0) is the main acid responsible for the increase in serum cholesterol (Madruga et al., 2006) and may cause a higher incidence of cardiovascular events. However, we didn't find an effect for C16:0 in lamb meat feeding with canola grain.

Among the PUFAs, only eicosatrienoic acid (C20:3 $\omega 3)$ was influenced by canola grain levels, which linearly decreased, as shown in Table 4 . This is probably explained by the low concentration of these FA in canola grain (Table 1). Fatty acids with unsaturation in carbon $\omega 3$ are considered beneficial to human health (Pelegrini et al., 2007), and some studies report benefits against diseases, such as cancer. It is 
believed that different mechanisms like transport through the membrane and immune functions contribute alone or in combination to improve the pathological condition (Yang et al., 2013).

In this study, the mean levels of SFA (43.55\%) and PUFA $(6.64 \%)$ were similar among the treatments $(\mathrm{p}>0.05)$ and lower than those observed by Madruga et al. (2006), which evaluated the fatty acids profile in muscles of Santa Ines lambs and verified values of $44.47 \%$ for SFA and $12.33 \%$ for PUFA. For MUFA, there was a higher concentration $(\sim 0.5 \%)$ in the meat of lambs that were not fed with canola grain than the treatments with 8 or $16 \%$ of grain inclusion in the diet (Table 4). Lamb meat is rich in saturated and monounsaturated fatty acids, with small amounts of polyunsaturated fatty acids (Leão et al., 2012), confirming the results obtained herein for SFA, MUFA, and PUFA.

There was a linear reduction in $\omega 3$ acid and $\omega 3: \omega 6$ ratio, Hence, the relationship $\omega 6: \omega 3$ increased with the inclusion of canola grain (Table 4). The $\omega 6: \omega 3$ ratio has been used as one of the criteria for assessing the quality of fat (Bentes et al., 2009), which should be lower than 4 (Pelegrini et al., 2007; Smeti et al., 2018). Thus, this index was considered satisfactory for all the treatments. The high intake of PUFA $\omega 6$ associated with low intake of PUFA $\omega 3$ causes physiological changes that trigger pro-inflammatory, pro-thrombotic states with increased vasospasm, vasoconstriction, and blood viscosity, favoring the onset of diseases (Patterson et al., 2012). The $\omega 6$ and $\omega 3$ FA have different roles in the human organism. Whereas the metabolic products of $\omega 6 \mathrm{FA}$ promote inflammation and tumors, $\omega 3 \mathrm{FA}$ acts in the opposite direction. Therefore, it is important to keep a dietary balance between the two types of FA, since they work together, promoting health and organic balance (Oliveira et al., 2013).

Statistical difference was detected for atherogenicity index (AI) (Table 4). The increase in the AI values ( 2\%) may be due to reduction of MUFA and PUFA $\omega 3$, despite the reduction of C12:0 acid with the inclusion levels, since this index indicates the ratio of the sum of the main saturated fatty acids (C12:0, C14:0, and C16:0) and the sum of the main unsaturated (MUFA and PUFA, $\omega 3$ and w6) (Ulbricht \& Southgate, 1991). The observed values for AI were 0.57 for the treatment with $0 \%$ inclusion and 0.58 for treatments with $8 \%$ and $16 \%$ inclusion of canola grain. This index remained within the normal range, according to Bobe et al. (2004), who stated that the fat of the meat has values between 0.5 and 1.0 .

Additionally, there was a linear increase for the thrombogenicity index (TI), according to the inclusion levels of canola grain in the diet (Table 4). TI considers myristic (C14:0), palmitic (C16:0), and stearic (18:0) as thrombogenic acids and PUFA $\omega 6$ and $\omega 3$ and MUFA, as anti-thrombogenic acids (Ulbricht \& Southgate 1991). As previously mentioned, the acids C14:0 decreased with the inclusion of canola grains, as also occurred for $\omega 3$ and MUFA, thus causing an increase in TI ( 2\%).

AI and TI indicate the stimulus potential of platelet aggregation. That is, the lower the values of AI and TI, the greater the amount of antiatherogenic FA present in certain fat or oil. Therefore, the higher the platelet aggregation, the greater the potential to prevent coronary heart disease (Turan et al., 2007).

For Santos-Silva et al. (2002), the best way to assess the nutritional value of the fatty acid profile is the use of ratios based on functional effects of FA, for example, the ratio of hypocholesterolemic (h) / hypercholesterolemic (H) FA. This ratio is an index that considers the functional activity of FA on the metabolism of lipoprotein transporting plasma cholesterol, whose type and quantity are related to increased or decreased risk of incidence of cardiovascular disease.

There was a reduction in the hypocholesterolemic: hypercholesterolemic ratio, with mean values of 2.09 for a diet with $0 \%$ inclusion, and 2.06 for $8 \%$ and $16 \%$ inclusion of canola grain in the diet (Table 4). The reference for meat products is the value of 2.0 for the $\mathrm{h}$ : $\mathrm{H}$ ratio (Santos-Silva et al., 2002). Values higher than 2.0 represent products with a desirable FA composition in the nutritional aspect, as they mostly consist of hypocholesterolemic FA and, thus, reduce the risk of cardiovascular disease (Frota et al., 2010). In this way, despite the reduction $(\sim 1 \%)$ in the h: $\mathrm{H}$ ratio with the inclusion levels of canola grains, the observed values were satisfactory for all the treatments, which were above 2.0.

Regarding the sensory properties, there were no differences $(p>0.05)$ for the attributes evaluated, whose mean values were 2.12 for odor; 2.09 for flavor; 1.60 for tenderness, and 1.93 for overall evaluation (Table 5 ). These values correspond to 'like moderately' in the hedonic scale, which is indicative of good acceptability of the meat, even when the canola grain was added in high amounts in the fed diet. For purchase intention, the mean value $(\sim 2)$ corroborates this affirmation, which means that the testers will 'probably buy' the meat products. Sekali et al. (2016) also found that the inclusion of canola meal in the fed diet of Mutton Merino lambs did not affect the sensory acceptance of the meat.

The mean value for tenderness (1.60) in the subjective evaluation (sensory analysis) is per the shear force ( $3.48 \mathrm{kgf}$ ) checked in objective technique (instrumental analysis), 
Table 5 - Sensory properties of the Biceps femoris muscle of lambs finished with increasing levels of canola grain in the diet

\begin{tabular}{|c|c|c|c|c|}
\hline \multirow{2}{*}{ Variable } & \multicolumn{3}{|c|}{ Level of canola grain (\%) } & \multirow{2}{*}{$\operatorname{Pr}>\mathrm{F}$} \\
\hline & 00 & 08 & 16 & \\
\hline Odor & 2.72 & 1.82 & 1.83 & 0.1034 \\
\hline Flavor & 2.23 & 2.00 & 2.03 & 0.1358 \\
\hline Tenderness & 1.41 & 1.72 & 1.66 & 0.1077 \\
\hline Overall evaluation & 2.05 & 1.97 & 1.76 & 0.1242 \\
\hline Purchase intent & 2.14 & 2.00 & 1.90 & 0.1434 \\
\hline
\end{tabular}

indicating that the addition of canola seed promoted satisfactory sensory characteristics. Sensory analysis is an important tool for assessing meat quality. However, the simultaneous application of instrumental techniques can specify more effectively the acceptance of the product on the market (Monte et al., 2012). Meat tenderness is a major attribute in the overall impression of the consumer and it can be defined as the facility to chew the meat. This parameter may be composed of three sensations perceived by the consumer: an initial sensation of ease of penetration of the meat by the teeth, another sensation, more prolonged, which is the resistance imposed by the meat to rupture during chewing, and the final sensation referring to the amount of residue remaining in the mouth (Monte et al., 2012).

\section{References}

Association of Official Analytical Chemists - AOAC. Official methods of analysis. 19th ed. Washington: AOAC; 2000.

Bentes AS, Souza HAL, Mendonca XMFD, Simões MG. Physical and nutritional characterization and lipid profile of three amazon fish species. Braz J Agroind Technol. 2009;3(2):97-108.

Bobe G, Zimmerman S, Hammond EG, Freeman AEG, Lindeberg GL. Texture of butters made from milks differing in indices of atherogenicity. Anim Ind Rep. 2004;650:1-3. https://doi.org/10.31274/ans_air-180814-691.

Bonacina MS, Osório MTM, Osório JCS, Corrêa GF, Hashimoto JH. The influence of sex and finishing system on carcass and meat quality of Texel $\times$ Corriedale lambs. Rev Bras Zootec. 2011;40(6):1242-9. http://dx.doi.org/10.1590/ S1516-35982011000600012.

\section{Conclusion}

Overall, although several differences in fatty acid concentration were found, the absolute changes were rather small and likely related to the high efficiency of PUFA biohydrogenation in the rumen.

\section{Conflicts of Interest}

None.

\section{Ethics Statement}

The research was conducted under the approval of the Ethics Committee on Animal Experimentation (021/2012), of Federal University of Grande Dourados.

\section{Acknowledgements}

To the Coordination for the Improvement of Higher Education Personnel (CAPES) and the Federal University of Grande Dourados for financial support and scholarships. To the Foundation for Support the Development of Education, Science and Technology of the State of Mato Grosso do Sul (FUNDECT) and National Council for Scientific and Technological Development (CNPq - Brazil) for financing part of this work. To Fabíola Ortega de Lima and Mariana Belloni for assistance in OPG analysis.

Bouton PE, Harris PV, Shorthose WR. Effect of ultimate $\mathrm{pH}$ upon the water-holding capacity and tenderness of mutton. J Food Sci. 1971;36(3):435-9. http://dx.doi. org/10.1111/j.1365-2621.1971.tb06382.x.

Buccioni A, Decandia M, Minieri S, Molle G, Cabiddu A. Lipid metabolism in the rumen: new insights on lipolysis and biohydrogenation with an emphasis on the role of endogenous plant factors. Anim Feed Sci Technol. 2012;174(1-2):1-25. http://dx.doi.org/10.1016/j.anifeedsci.2012.02.009.

Caldeira LA, Ferrão SPB, Fernandes SAA, Magnavita AP, Santos TDR. Nutritional quality indexes of lipid fraction of milk from Murrah buffalo, produced at different stages of lactation. Rev Inst Adolfo Lutz. 2010;69(4):545-54.

Campo MM. Estandarización de las metodologias para evaluar la calidad del produto (animal vivo, canal, carne y 
grasa) em los rumiantes. Madrid: INIA Cañeque \& Sañudo; 2005. Chap. 8, p. 409-22.

Cañeque V, Sañudo C. Metodología para el estúdio de la calidad de la canal y de la carne en rumiantes. Madrid: Instituto Nacional de Investigación y Tecnología y alimentaria; 2000.

Cezar MF, Souza WH. Carcaças ovinas e caprinas - obtenção, avaliação e classificação. Uberaba: Agropecuária Tropical; 2007.

Costa RG, Santos NM, Sousa WH, Queiroga RCRE, Azevedo PS, Cartaxo FQ. Qualidade física e sensorial da carne de cordeiros de três genótipos alimentados com rações formuladas com duas relações volumoso: concentrado. Rev Bras Zootec. 2011;40(8):1781-7. http://dx.doi.org/10.1590/ S1516-35982011000800023.

Folch J, Lees M, Stanley GHS. A simple method for the isolation and purification of total lipids from animal tissues. J Biol Chem. 1957;226(1):497-509. http://dx.doi.org/10.1016/ S0021-9258(18)64849-5. PMid:13428781.

Frota KMG, Matias ACG, Areas JAG. Influence of food components on lipid metabolism: scenarios and perspective on the control and prevention of dyslipidemias. Food Sci Technol. 2010;30(suppl. 1):7-14. http://dx.doi.org/10.1590/ S0101-20612010000500002.

Gallo SB, Siqueira ER, Rosa GT. Efeito da nutrição da ovelha e do cordeiro sobre o perfil de ácidos graxos do músculo Triceps brachii de cordeiros. Rev Bras Zootec. 2007;36(suppl. 6):2069-73. http://dx.doi.org/10.1590/ S1516-35982007000900017.

Kim EJ, Huws S, Lee M, Scollan N. Dietary transformation of lipid in the rumen microbial ecosystem. Asian-Australas J Anim Sci. 2009;22(9):1341-50. http://dx.doi.org/10.5713/ ajas.2009.r.11.

Kišidayová S, Mihaliková K, Siroka P, Čobanová K, Váradyová Z. Effects of inorganic and organic selenium on the fatty acid composition of rumen contents of sheep and the rumen bacteria and ciliated protozoa. Anim Feed Sci Technol. 2014;193:51-7. http://dx.doi.org/10.1016/j. anifeedsci.2014.04.008.

Leão AG, Silva Sobrinho AG, Moreno GMB, Souza HBA, Giampietro A, Rossi RC, Perez HL. Physic-chemical and sensorial characteristics of meat from lambs finished with diets containing sugar cane or corn silage and two levels of concentrate. Rev Bras Zootec. 2012;41(5):1253-62. http:// dx.doi.org/10.1590/S1516-35982012000500024.

Lira GM, Mancini-Filho J, Torres RP, Oliveira AC, Vasconcelos AMA, Omena CMB, Almeida MCS. Centesimal composition, caloric value, level of cholesterol, and fatty acid profile of the meat from buffalo (Bubalis bubalis) breeding in the area of São Luiz do Quitunde-AL. Rev Inst Adolfo Lutz. 2005;64(1):31-8.

Little KL, Bohrer BM, Maison T, Liu Y, Stein HH, Boler DD. Effects of feeding canola meal from high-protein or conventional varieties of canola seeds on growth performance, carcass characteristics, and cutability of pigs. J Anim Sci. 2015;93(3):1284-97. http://dx.doi.org/10.2527/jas.2014-8359.

Loor JJ, Ueda K, Ferlay A, Chilliard Y, Doreau M. Biohydrogenation, duodenal flow, and intestinal digestibility of trans fatty acids and conjugated linoleic acids in response to dietary forage: concentrate ratio and linseed oil in dairy cows. J Dairy Sci. 2004;87(8):2472-85. http://dx.doi. org/10.3168/jds.S0022-0302(04)73372-X. PMid:15328271.

Madruga MS, Araújo WO, Sousa WH, Cézar MF, Galvão MS, Cunha MGG. Efeito do genótipo e do sexo sobre a composição química e o perfil de ácidos graxos da carne de cordeiros. Rev Bras Zootec. 2006;35(suppl. 4):1838-44. http://dx.doi.org/10.1590/S1516-35982006000600035.

Monte ALS, Gonsalves HRO, Villarroel ABS, Damaceno MN, Cavalcante ABD. Qualidade da carne de caprinos e ovinos: uma revisão. Agropec Cient Semi-Árido. 2012;8(3):11-7.

Mu C, Yang W, Wang P, Zhao J, Hao X, Zhang J. Effects of high-concentrate diet supplemented with grape seed proanthocyanidins on growth performance, liver function, meat quality, and antioxidant activity in finishing lambs. Anim Feed Sci Technol. 2020;266:114518. http://dx.doi. org/10.1016/j.anifeedsci.2020.114518.

National Research Council - NRC. Nutrient requirements of small ruminants: sheep, goats, cervids, and new world camelids. New York: NRC; 2007. https://doi.org/10.17226/11654.

Oliveira AC, Silva RR, Oliveira HC, Almeida VVS, Garcia RF, Oliveira ULC. Influência da dieta, sexo e genótipo sobre o perfil lipídico da carne de ovinos. Arch Zootec. 2013;62:57-72. http://dx.doi.org/10.21071/az.v62iREV.1957.

Oliveira RL, Ladeira MM, Barbosa MAAF, Assunção DMP, Matsushita M, Santos GT, Oliveira RL. Ácido linoléico conjugado e perfil de ácidos graxos no músculo e na capa de 
gordura de novilhos bubalinos alimentados com diferentes fontes de lipídios. Arq Bras Med Vet Zootec. 2008;60(1):16978. http://dx.doi.org/10.1590/S0102-09352008000100024.

Osório JCS, Osório MTM, Oliveira NM, Siewerdt L. Qualidade, morfologia e avaliação de carcaças. Pelotas: Universidade Federal de Pelotas; 2012.

Patterson E, Wall R, Fitzgerald GF, Ross RP, Stanton C. Health implications of high dietary omega- 6 polyunsaturated Fatty acids. J Nutr Metab. 2012;2012:539426. http://dx.doi. org/10.1155/2012/539426. PMid:22570770.

Pelegrini LFV, Pires CC, Kozloski GV, Terra NN, Baggio SR, Campagnol PCB, Galvani DB, Chequim RM. Perfil de ácidos graxos da carne de ovelhas de descarte de dois grupos genéticos submetidas a dois sistemas de manejo. Cienc Rural. 2007;37(6):1786-90. http://dx.doi.org/10.1590/ S0103-84782007000600044.

Pinheiro RSB, Jorge AM, Souza HBA, Boiago MM. Coloração da gordura e qualidade da carne de ovelhas de descarte abatidas em distintos estágios fisiológicos. Arq Bras Med Vet Zootec. 2010;62(2):468-74. http://dx.doi.org/10.1590/ S0102-09352010000200029.

Pinheiro RSB, Jorge AM, Souza HBA. Sensorial acceptance and centesimal composition in the meat of ewes slaughtered in different physiological stages. Arq Bras Med Vet Zootec. 2012;64(4):1053-9. http://dx.doi.org/10.1590/S010209352012000400035 .

Pinheiro RSB, Silva Sobrinho AG, Souza HBA, Yamamoto SM. Qualidade de carnes provenientes de cortes da carcaça de cordeiros e de ovinos adultos. Rev Bras Zootec. 2009;38(9):1790-6. http://dx.doi.org/10.1590/S151635982009000900022 .

Quiñones J, Maggiolino A, Bravo S, Muñoz E, Lorenzo JM, Cancino D, Díaz R, Saenz C, Sepúlveda N, De Palo P. Effect of canola oil on meat quality and fatty acid profile of Araucano creole lambs during fattening period. Anim Feed Sci Technol. 2019;248:20-6. http://dx.doi.org/10.1016/j. anifeedsci.2018.12.002.

Radmann EM, Costa JAV. Conteúdo lipídico e composição de ácidos graxos de microalgas expostas aos gases $\mathrm{CO} 2$, SO2 e NO. Quim Nova. 2008;31(7):1609-12. http://dx.doi. org/10.1590/S0100-40422008000700002.

Ripoll G, Albertí P, Joy M. Influence of alfalfa grazing-based feeding systems on carcass fat colour and meat quality of light lambs. Meat Sci. 2012;90(2):457-64. http://dx.doi. org/10.1016/j.meatsci.2011.09.007. PMid:21983425.

Rocha LAC. Qualidade do leite de búfala e desenvolvimento de bebida láctea com diferentes níveis de iogurte e soro de queijo [dissertation]. Itapetinga: Universidade Estadual do Sudoeste da Bahia; 2008.

Saldanha ESPB, Gonzales E. Enriquecimento de ácidos graxos na alimentação de poedeiras. Pesqui Tecnol. 2012;9(1):1-5.

Santos VC, Ezequiel JMB, Pinheiro RSB, Barbosa JC, Galati RL. Carcass characteristics in lambs fed with grains and by-products of canola. Acta Sci Anim Sci. 2009;31(4):38995. http://dx.doi.org/10.4025/actascianimsci.v31i4.6946.

Santos-Silva J, Bessa RJB, Santos-Silva F. Effect of genotype, feeding system and slaughter weight on the quality of light lambs: fatty and composition of meat. Livest Prod Sci. 2002;77(2):187-94. http://dx.doi.org/10.1016/S03016226(02)00059-3.

Sañudo C, Enser ME, Campo MM, Nute GR, Maria G, Sierra I, Wood J. Fatty acid composition and sensory characteristics of lamb carcasses from Britain and Spain. Meat Sci. 2000;54(4):339-46. http://dx.doi.org/10.1016/ S0309-1740(99)00108-4. PMid:22060790.

Sekali M, Marume U, Mlambo V, Strydom PE. Growth performance, hematology, and meat quality characteristics of Mutton Merino lambs fed canola-based diets. Trop Anim Health Prod. 2016;48(6):1115-21.http://dx.doi.org/10.1007/ s11250-016-1058-x. PMid:27126221.

Smeti S, Hajji H, Mekki I, Mahouachi M, Atti N. Effects of dose and administration form of rosemary essential oils on meat quality and fatty acid profile of lamb. Small Rumin Res. 2018;158:62-8. http://dx.doi.org/10.1016/j. smallrumres.2017.10.007.

Turan H, Sönmez G, Kaya Y. Fatty acid profile and proximate composition of the thornback ray (Raja clavata, L. 1758) from the Sinop coast in the Black Sea. J Fish Sci. 2007;1(2):97103. http://dx.doi.org/10.3153/jfscom.2007012.

Ulbricht TLV, Southgate DAT. Coronary heart disease: seven dietary factors. Lancet. 1991;338(8773):985-92. http:// dx.doi.org/10.1016/0140-6736(91)91846-M. PMid:1681350.

Wada FY, Prado IN, Silva RR, Moletta JL, Visentainer JV, Zeoula LM. Whole linseed and canola seed on performance apparent digestibility and carcass characteristics of nellore 
heifers finished in feedlot. Cienc Anim Bras. 2008;9(4):88395. http://dx.doi.org/10.5216/cab.v9i4.1135.

Yamamoto SM, Silva Sobrinho AG, Pinheiro RSB, Leão AG, Castro DPV. Inclusion of sunflower seeds in the diet of lambs on carcass quantitative characteristics and meat quality. Semina: Ciênc Agrár. 2013;34(4):1925-34. http:// dx.doi.org/10.5433/1679-0359.2013v34n4p1925.

Yang T, Fang S, Zhang HX, Xu LX, Zhang ZQ, Yuan KT, Xue CL, Yu HL, Zhang S, Li YF, Shi HP, Zhang Y. N-3 PUFAs have antiproliferative and apoptotic effects on human colorectal cancer stem-like cells in vitro. J Nutr Biochem. 2013;24(5):744-53. http://dx.doi.org/10.1016/j. jnutbio.2012.03.023. PMid:22854319.
Zeola NMBL, Souza PA, Souza HBA, Silva Sobrinho AG. Qualitative parameters of lamb meat: a focus in ageing and marination. Rev Port Ciênc Vet. 2007;102(563):215-24.

Financial Support: Coordination for the Improvement of Higher Education Personnel (CAPES) and the Federal University of Grande Dourados for financial support and scholarships. To the Foundation for Support the Development of Education, Science and Technology of the State of Mato Grosso do Sul (FUNDECT) and National Council for Scientific and Technological Development (CNPq - Brazil) for financing part of this work. 